Поиулко О. А., кандидат історичних наук, доцент, доцент кафьедри мовних та гуманітарних дисииплін № 1 Донецького національного медичного університету

Давидов П. Г., кандидат фбілософбських наук, доцент, доцент кафьедри мовних та гуманітарних дисииплін № 1 Донецького національного медичного університету

\title{
«ЗАКОН РЕКОМБІНАЦІЙНИХ ПЕРЕТВОРЕНЬ» Д. С. САРКІСОВА - ЧЕТВЕРТИЙ ЗАКОН ФІЛОСОФІЇ
}

Анотація. У статті проаналізовані, 3 одного боку, основні віхи біографії чудової людини, академіка Доната Семеновича Саркісова, які вплинули на становлення його як ученого, який залишив після себе величезну кількість як теоретичних, так і практичних напрацювань в клінічній, загальній, патологічній медицині, а також філософії, 3 іншого боку, основні етапи зародження та становлення теорії регенерації, яка своєю чергою стала основою відкриття 4-го закону філософії - «Закону рекомбінаційних перетворень». Глибокий і принциповий «сенс» рекомбінаційних перетворень у живих системах полягає в тому, що без них у величезній кількості випадків не можуть працювати такі найважливіші «кількісні» адаптивні процеси організму, як регенерація і гіперплазія: в цих умовах вони втрачають одну зі своїх головних властивостей - специфічність по відношенню до певного патогенного фактору.

Чому сьогодні Д.С. Саркісов - єдиний в світі автор відкриття в філософії - науці, що має в своєму арсеналі багато великих відкриттів? Справа в тому, що відкриття законів, категорій, понять філософії в їх сучасному формулюванні це колективна праця багатьох великих умів людства. Практично всі основні положення діалектики були висловлені ще античними авторами. Ці висловлювання, хоча й не дуже чіткі, слабо доведені, з елементами геніальних здогадок і наївних фантазій, тим не менш, були вже філософськими, тобто мають не приватне, а загальне, вселенське значення, що поширюється на всі явища світу. Філософи більш пізньої доби, в тому числі і сучасні, ці положення уточнювали, розвивали, узгоджували 3 лавиноподібно наростаючим матеріалом природничих наук. У Д.С. Саркісова ситуація інша. Комбінаційні перетворення теж були відомі і використовувалися людиною давно. Але всі вони так і залишалися окремими випадками, до моменту, коли Д.С. Саркісов зрозумів, що всі ці факти - часткові прояви загального, тобто філософського, закону, що поширюється на живу і неживу природу, суспільство і мислення, закону, що виражає форму руху матерії, котра до нього ще не була описана. Тому цілком справедливо присудження Д.С. Саркісову пріоритету у цьому відкритті.

Ключові слова: загальна патологія, внутрішньоклітинна регенерація, закон рекомбінаційних перетворень, клінічна медицина, тканина, експеримент.

Постановка проблеми. Звернення до особистості Доната Семеновича Саркісова й сьогодні є дуже актуальним, адже своїм життям він довів безумовну необхідність зацікавле- ного ставлення до навколишнього світу. Так, він надзвичайно зацікавлено ставився до всіх явищ суспільного життя - істоpiї, медицини, культури, мистецтва, політики, прекрасно знав і любив російську літературу. Радо спілкувався 3 різними людьми і сам був дуже зацікавлений у таких розмовах, де розкривалась чарівність багатого людського духовного світу. Мав добре почуття гумору, його жарти постійно ставали надбанням інститутського фольклору. У нього є чудові твори про історію своєі країни, війну, медицину, про роль видатних медиків, про творчість одного з його улюблених письменників А.П. Чехова. Проте найбільш значущу сторінку своєї біографії Д.С. Саркісов залишив саме в медицині.

Він розпочав свою медичну кар'єру 3 досконального вивчення прозекторської й біопсійної справи й не припиняв нею займатися до кінця життя, він власноруч робив препарат краще за досвідченого лаборанта. Може саме тому він свій шлях у науці розпочав з ретельного вивчення техніки експерименту, що дозволяло йому майже безпомилково, тільки за описом досвіду, орієнтуватися в достовірності тих чи інших даних. Першою 3 основних ідей Доната Семеновича була теорія внутрішньоклітинної регенерації, яка лягла в основу «Закону рекомбінаційних перетворень».

Саме цьому відкриттю - 4-му закону філософії, який за своєю сутністю є розвитком положення про рух як про форму існування матерії, про взаємовідносини між синтезом і розпадом речовин, які представляють собою основне внутрішнє протиріччя процесу життєдіяльності і його головну рушійну силу, присвячена ця стаття.

Аналіз останніх досліджень і публікацій. У публікаціях, присвячених різним проблемам патології, про значення рекомбінаційних перетворень до Д.С. Саркісова [4-7] зовсім не згадувалося, а в роботах біохімічного, молекулярного профілю на них вказують без будь-якого зв'язку з їх найважливішим значенням для розробки питань клінічної медицини. I тільки після смерті видатного вченого його теорії, вчення та закон привернули увагу дослідників - тих, хто поруч із самим С.Д. Саркісовим займалися проблемами внутрішньоклітинної регенерації та комбінаційними перетвореннями, - Л.Б. Лазебника, О.Л. Вьорткіна, Ю.В. Конєва, Е.Д. Лі, О.С. Скотнікова [1], О.О. Пальцина, Є.Г. Колокольчикової $[2,3]$. Проте їм у своїх роботах, на жаль, так і не вдалося зрозуміти до кінця всю значущість та місце в сучасній історії філософії концепції Д.С. Сар- 
кісова як 4-го закону філософії, оскільки це, безумовно, тема для самостійного повноцінного наукового дослідження.

Мета статті - надати коротку біографічну довідку про академіка Доната Семеновича Саркісова, а також проаналізувати основні етапи відкриття 4-го закону філософії від зародження ідеї внутрішньоклітинної регенерації до створення принципово нової теорії про комбінаційні перетворення.

Виклад основного матеріалу. Донат Семенович Саркісов народився в Москві 5 вересня 1924 р. Його батько С.А. Саркісов - відомий радянський невропатолог-нейроморфолог, засновник і багаторічний директор Інституту мозку АМН СРСР, мати - дитячий лікар. Дев'ять класів середньої школи Д.С. Саркісов закінчив у 1941 р. в Москві, а десятий клас - у 1942 р. в Казані, куди був евакуйований з батьками. Влітку 1942 р. Д.С. Саркісов був призваний до лав радянської армії і військкоматом спрямований у Військово-морську медичну академію, яка тоді була евакуйована 3 м. Ленінград до м. Кіров [2, с. 47]. Так почався шлях Д.С. Саркісова в медицині, який тривав близько 60 років.

Перший і другий курси Академії (1942-1943рp.) пройшли в м. Кірові. Влітку 1944 р. Академія стала одним із перших вищих навчальних закладів, що повернулися до Ленінграду. Цей навчальний заклад був організований ще до війни на базі одного 3 найстаріших лікувальних закладів країни - колишньої Обухівської лікарні. Військово-морська медична академія (BMMA) була однією з найбільш авторитетних вищих навчальних медичних закладів країни, відомою своїм видатним професорсько-викладацьким складом і багатими традиціями. Все це мало для ще молодого Доната Саркісова величезне виховне значення: спілкування не тільки 3 майстрами своєї справи, а й широко освіченими викладачами, людьми високої культури, добре знайомими з історією, літературою, мистецтвом.

Більша частина курсантів, які закінчили ВММА, стали професорами, багато - завідувачами кафедр, членами АМН СРСР, відомими вченими та організаторами охорони здоров'я, відзначеними високими урядовими нагородами. Після закінчення BMМА в 1947 р. Д.С. Саркісов був направлений на роботу до Науково-дослідного морського медичного інституту ВМС, де на посаді наукового співробітника став спеціалізуватися в галузі морфології як єдиний фахівець. Саме тут почалася довга, досить плідна і різнобічна робота Д.С. Саркісова в галузі медичної науки і практики.

Дуже важливим моментом у своєму житті Д.С. Саркісов вважав значно ближче знайомство, ніж у курсантські роки, з професором С.С. Вайлем - опонентом його кандидатської дисертації. Саме С.С. Вайль розгледів споріднену душу у Д.С. Саркісову та запропонував йому перейти працювати на очолювану ним кафедру патологічної анатомії ВММА. 3 тих пір С.С. Вайль став його улюбленим учителем, якому, як вважав Д.С. Саркісов, він зобов' язаний усім - «вихованням його в класичній московській (С.С. Вайль - учень А.І. Абрикосова) патологоанатомічній школі, прищепленням любові до прозекторської справи, до медичної науки, іiі історії (С.С. Вайль був відомим істориком медицини), літератури, мистецтва, філософських підвалин медицини, тобто до всього того, що є головним у житті вченого, але що так нелегко зустріти на своєму шляху» [3, с. 72]. У цих словах самого Д.С. Саркісова є деяка гіпербола, природна для людини, сповненої любові й вдячності до свого вчителя. Безсумнівно, Д.С. Саркісов був щедро обдарований природою, але безсумнівно також і те, що С.С. Вайль сприяв розвитку його природного дару. Сам Д.С. Саркісов вважав, що його вчитель був уособленням того, що сам він уявляв для себе головним у людині взагалі і як вченого зокрема, - скромності, порядності, доброго ставлення до людей, доброзичливості.

У 1955 р. Д.С. Саркісов захистив докторську дисертацію, присвячену впливу порушень морфології і функції головного мозку на перебіг та наслідки експериментальної пневмонії. 3 цієї роботи почалися його багаторічні й різноманітні дослідження у сфері функціональної морфології.

Саме ці дослідження надали великий фактичний матеріал для обгрунтування тези про нерозривну єдність структури i функції, тобто він вказав на неможливість «чисто функціональних змін» або компенсації будь-якого навантаження або пошкодження «функціональною напругою», як деякі, на жаль, продовжують вважати і сьогодні.

У 1956 р. ВММА була закрита і перетворена на факультет BMA ім. С.М. Кірова 3 підготовки військово-морських лікарів. Протягом деякого часу Д.С. Саркісов був старшим викладачем кафедри патологічної анатомії ВМА ім. С.М. Кірова, але в 1958 р. він демобілізувався і пройшов за конкурсом на посаду завідувача відділом патологічної анатомії Інституту хірургії iм. А.В. Вишневського АМН СРСР у Москві, яким завідував 42 роки. Розставання 3 вже неіснуючою кафедрою патологічної анатомії ВММА (вона була об'єднана з однойменною кафедрою Військово-медичної академії), іiі колективом і особливо зі своїм учителем було тяжким і сумним.

Першим напрямом робіт, який намітився після переїзду Д.С. Саркісова до Москви, було вивчення оборотності хронічних змін внутрішніх органів. Такий напрям дослідження визначився характерною особливістю діяльності Д.С. Саркісова. Він усе життя був насамперед лікарем. Будучи за складом свого розуму талановитим філософом, теоретиком, людиною, здатною знаходити загальні закономірності, зв'язки явищ, він завжди тримався клінічного напряму у своїй діяльності, дослідженнях і думках. Головне своє призначення Д.С. Саркісов бачив в тому, щоб, займаючись, здавалося б, далекими від практики теоретичними дослідженнями, прагнути того, щоб передусім принести користь лікувальній справі. Проведене ним вивчення хронічних змін внутрішніх органів диктувалося саме клінікою.

Якщо раніше проблема оборотності хронічних змін внутрішніх органів не привертала до себе серйозну увагу i була переважно суто теоретичною, то коли до неї звернувся Д.С. Саркісов, вона почала відігравати не останню роль у остаточній оцінці сучасних методів лікування і показань до їх застосування, тобто стала не меншою мірою і практичною. Важливого значення набули питання оборотності хронічних змін органів ще і у зв'язку з тим, що, незважаючи на майже необмежені можливості сучасної хірургії щодо проведення великих втручань на будь-якому з органів, однією з основних тенденцій (розвитку якої великою мірою сприяв Д.С. Саркісов) стала орієнтація на щадні операції, тобто на економні резекції патологічно змінених тканин: нирок, печінки, підшлункової залози, легень, з розрахунком на те, щоб зберегти якомога більшу частину тієї паренхіми, яка ще здатна виконувати функцію. Ця тенденція зумовлена тим, що час, коли компенсаторні можливості різних органів вважалися практично безмежними, пройшов. Величезний досвід клінічних і експериментальних 
спостережень підказував, що відносно невеликі ділянки тканин (легенів, нирок, підшлункової залози та ін.), які залишилися після великих резекцій, функціонують задовільно лише деякий час. Безперервно піддаючись великим функціональним навантаженням, вони «зношуються» швидше, ніж повноцінні органи. Тому актуальним для Д.С. Саркісова і клінічної медицини загалом стали такі питання, як: 1) оборотність хронічних змін взагалі і залежно від ступеня їх розвитку зокрема; 2) встановлення хоча б приблизно тих меж, перехід яких робить зміни незворотними; 3) терміни, протягом яких в тому чи іншому органі відбувається досить повне і стійке відновлення структури; 4) нарешті, умови, що сприяють цьому процесу або навпаки загальмовують його [3, с. 72]. Коли ж потрібні були чіткі відповіді на ці питання, то виявилося, що нічого конкретного $з$ цього приводу сказати не можна. Зрозуміло, що в умовах хірургічного інституту Д.С. Саркісов відразу ж зацікавився, що відбувається 3 тим чи іншим патологічно зміненим органом після видалення його частини або усунення хронічного навантаження, що супроводжується його вторинними змінами.

3 60-х рр. наукові дослідження Д.С. Саркісова почали все більше набувати теоретичного характеру, точніше, чіткіше стала вимальовуватися тенденція до теоретичної інтерпретації та узагальнення результатів патологоанатомічних і експериментальних робіт, які виконувалися в його відділі. Треба сказати, що за великої кількості робіт з окремих питань патологічної анатомії, за величезних знань, досвіду та майстерності його як діагноста, фахівця прозекторської і біопсійної справи саме загальна патологія стала його головним захопленням і любов'ю. Д.С. Саркісов переосмислив майже всю загальну патологію, вніс ясність і простоту істини щодо багатьох питань, привів загальну патологію у відповідність до усіх комплексів сучасних біологічних і медичних наук, до сучасної клінічної практики, до матеріалістичної діалектики, до еволюційної теорії. Загальна патологія як наука про основні закономірності виникнення, розвитку та наслідків хвороб людини виявилася істотною мірою оновленою і отримала потужний імпульс для свого подальшого розвитку. Підтвердити сказане можна, нагадавши основні постулати теоретичної і практичної медицини, що були модернізовані або радикально змінені Д.С. Саркісовим.

Перше, про що потрібно сказати, так це чітке фактичне обгрунтування Д.С. Саркісовим принципу єдності структури і функції, яке, з одного боку, не викликає сумнівів у філософському плані, а з іншого - донині залишаються ігнорованими у теоретичній і практичній медицині. Одним із доказів принципу стало спостереження, зроблене у відділі, очолюваному Д.С. Саркісовим, на основі електронно-радіоавтографічного вивчення ультраструктурних змін за різних режимів функціонального навантаження на орган. Виявилося, що коливання функціональної активності клітини супроводжуються змінами, які синхронно відбуваються 3 нею у внутрішньоклітинних структурах, починаючи 3 найелементарніших - біологічних макромолекул. Нанесення рани, наприклад, викликало підвищення рівня синтезу інформаційної та рибосомної РНК, гіперплазію гранулярного ендоплазматичного ретикулуму в фібробластах, що структурно забезпечувало посилення їх функції - утворення грануляційної тканини [3, с. 74].

Д.С. Саркісов створив теорію регенерації - стрижневого процесу життєдіяльності в нормі та патології. Основний постулат теорії йде від глибинних основ світобудови: в природі немає нічого, крім матерії і руху. Рушійна сила живої матеріїнерозривна єдність і боротьба двох протилежних начал: руйнування і творення, розпаду і синтезу, дисиміляції й асиміляції. Творення у всіх його формах іє регенерація. Іншими словами, регенерація - одна 3 двох складників явища під назвою життя. За теорією Д.С. Саркісова, регенерація не має тієї однобічно морфологічної спрямованості, яку ій приписували раніше. Регенерація виконує в природі структурно-функціональне завдання, вона забезпечує функцію шляхом постійного відтворення структур, що виконують цю функцію. Замість старого трактування регенерації як явища, пов'язаного з хворобою, Д.С. Саркісов доводить примат фізіологічної регенерації, що підтримує життєву функцію. I тільки в разі відхилення життя від нормального ходу через патологічний процес виникає репаративна регенерація, яка розвивається на базі фізіологічної i за тими самими механізмами, виражається в тих самих формах і має тільки кількісні відмінності від фізіологічної регенерації [2, с. 49]. Д.С. Саркісов стверджує, що регенераторна здатність не знижується у вищих тварин порівняно з нижчими, або в мозку порівняно зі шкірою. Еволюція змінює і ускладнює види тварин, їх органи та системи. Відповідно до цих змін змінюються і способи регенерації. Шляхи здійснення регенерації стають складнішими і різноманітнішими. Всі органи регенерують відповідно до своїх структурно-функціональних особливостей. У ссавців, на відміну від амфібій, на місці травми або руйнування органу патологічним процесом не відбувається відростання зниклої ділянки, а формується рубець. Проте орган може повністю регенерувати, тобто забезпечити нормальний рівень функції шляхом розмноження збережених клітин або гіперплазії в них ультраструктур. Останній спосіб регенерації Д.С. Саркісов назвав внутрішньоклітинною регенерацією [3, с. 74]. Відкриття внутрішньоклітинної регенерації дозволило йому експериментально обгрунтувати свою тезу про різноманітність форм регенерації. Передбачене теорією положення про збереження регенераторної здатності органами, в яких розмноження клітин відсутнє або слабо виражене, він пояснив тим, що регенерація в них відбувається за внутрішньоклітинним механізмом, і довів це. Отже, теорія Д.С. Саркісова висвітлила справжню форму явища регенерації, розкрила іiі місце і роль у живій природі, прояснила суть таких загальнопатологічних процесів, як атрофія, дистрофія, гіпертрофія.

У монографіях з регенерації [4-7] були викладені основні закономірності відновлення внутрішньоклітинних структур після їх пошкодження (строки регенерації, морфологічна характеристика цього процесу в різних органелах, критерії оборотних і необоротних змін тощо) і показано, що в органелах клітин різних органів (міокарда, печінки, легенів, нирок, підшлункової залози, нервової системи) відновлення протікає однотипно. Динаміка пошкодження органел і нормалізації їх структури після припинення патогенного впливу не відрізняються будьякою специфікою залежно від характеру етіологічного фактора (гіпоксія, опік, різні токсичні агенти, променева дія, механічна травма, підвищення функціонального навантаження тощо). Як в процесі нормального функціонування клітини, так і в умовах патогенних впливів нормалізація будови змінених органел завжди поєднується з їхньою гіперплазією.

Розмірковуючи про проблему адаптації, Д.С. Саркісов зрозумів, що теорія регенерації пояснює лише одну сторону цієі проблеми - кількісну, тобто механізми оновлення та гіперплазії 
числа структур, необхідного для виконання певної функції. Але механізми адаптації є складнішими. Щоб пристосування до дії нормальних і патогенних факторів середовища було більш повним, необхідна зміна не тільки числа, а й якості структур. Переглядаючи наявні способи зміни якості, він зрозумів, що в біологічних системах найбільш поширеним, ефективним і важливим способом рекомбінаційних перетворень. Що мається на увазі? Даний термін «рекомбінаційні перетворення» означає розташування складових частин будь-якої системи у новому порядку, що призводить до якісної зміни цієї системи. Ще К. Бернар писав: «Організація є результат суміші складних речовин, що реагують один на одного. На нашу думку, властивості, що властиві живій матерії, залежать від угруповання цих речовин, особливого, досить складного, але тим не менш підпорядкованого загальним хімічним законам угруповання матерії» [1, с. 53]. В основі рекомбінаційних перетворень лежать відомі з хімії явища ізомерії або конформації. Як вказує далі Д.С. Саркісов, найбільш вражаючі приклади явищ ізомерії і конформації можна почерпнути з генетики і біохімії. Так, наявні на цей час дані свідчать про те, що все нескінченне різноманіття ознак різних представників світової флори та фауни визначається варіантами поєднань всього 4 «літер-символів», точніше, чотирьох амінокислот (аденін, гуанін, цитозін і тимін). В процесі еволюції геному виникла складна система сполучень, що дозволяє чотирма «літерами» записувати не 4 якості, а нескінченне число якостей. Зміни просторового розташування структур, що супроводжуються функціональними порушеннями, можуть спостерігатися не тільки на молекулярному («молекулярні» хвороби), але і на тканинному рівні («соматичні», нервові і психічні хвороби). Останнє, зокрема, підтверджується даними, отриманими під час стереологічного дослідження конструкції нервової тканини.

Перетворення, про які йдеться, діють на усіх рівнях організації живої природи від молекули до біосфери. Ефективним способом пристосування видів тварин і рослин до змін середовища стало статеве розмноження і зумовлені ним генетичні рекомбінації. Завдяки йому всі нащадки за однакового числа генів розрізняються як між собою, так і з кожним з батьків, тому що комбінація генів кожного 3 них індивідуальна (через встановлений Г. Менделем закон незалежного успадкування алелів). Таким чином, за кількісно однакового геному з'являється безліч різноманітних індивідуумів, виникає мінливість, яка є однією з умов адаптації виду до середовища і його збереження на планеті. Нервова система теж працює за принципом рекомбінації. Навіть за зміни одного виду фізичної роботи на інший, а тим більше під час переходу до відпочинку, в процесі формування різних емоцій, виникнення різних думок, під час слухання або розмови, звичайно змінюється число «задіяних» в процесі нейронів. Але не тільки цим забезпечується зміна функції мозку. Ще більше значення мають підключення до функції або відключення від неї якісно різних груп нейронів і зміна зв'язків між ними, а це і є рекомбінаційні перетворення системи (мозку), що дозволяє успішніше виконувати зазначені i не зазначені тут функції.

Рекомбінаційний механізм адаптації досить ефективний внаслідок своєї економічності, що дозволяє живій системі здійснювати найширший спектр пристосувальних реакцій швидше i, що не менш важливо, без створення нових структур і збільшення обсягу системи. Принцип рекомбінаційних пере- творень у межах тієї чи іншої системи притаманний усім видам матерії, але далеко не рівною мірою. В органічній природі, особливо у вищих тварин, діапазон цих перетворень ширший, вони незрівнянно різноманітніші, ніж в неорганічної природи, і мають зовсім іншу «цільову» спрямованість. Якщо в неорганічній природі вони відбуваються як би спонтанно, внаслідок чисто механічного збігу обставин, то у тварин рекомбінаційні зміни в процесі еволюції відігравали все зростаючу роль в удосконаленні компенсаторно-пристосувальних реакцій. Можна припустити, що рекомбінаційні перетворення - один з головних шляхів еволюції в напряму підвищення ефективності механізмів пристосування шляхом удосконалення їх якості, що зберігаються незмінними, в рамках всієї системи. Якісні зміни можуть виникати як без попередніх їм кількісних змін, що є складовими елементами системи, тобто на основі винятково рекомбінаційних їх перетворень, так і шляхом додавання або зменшення числа структурних елементів, тобто на основі «переходу кількісних змін у якісні». Проте значно частіше виникнення нової якості системи відбувається за умови поєднання кількісних і рекомбінаційних змін їі структурних елементів. Обидва варіанти появи якісних змін біологічних систем, що засновані як на рекомбінаційних перетвореннях, так і на кількісних додатках, являють собою дві нерозривно пов'язані між собою складові частини різних реакцій організму взагалі і компенсаторно-пристосувальних зокрема. В цьому разі варто говорити про переважно синхронне розгортання в організмі кількісних і якісних змін пристосувального характеру.

Друзі-вчені Д.С. Саркісова, які вирішили після його смерті домогтися офіційного закріплення за ним пріоритету в цьому відкритті, сформулювали його концепцію як закон «Про рекомбінаційні перетворення в живих системах, що призводять до якісних змін цих систем (Закон рекомбінаційних перетворень)» - 4-й закон філософії, закон Д.С. Саркісова. У квітні 2004 р. Міжнародна академія авторів наукових відкриттів і винаходів видала диплом на це відкриття. «Встановлено невідомий раніше закон комбінаційних перетворень, який полягає в тому, що властивості системи (живої та неживої природи) визначаються поєднанням складників іiі елементів і змінюються під час їх перестановки, перегрупування, рекомбінації (закон матеріалістичної діалектики)» [3, с. 78]. Жодна людина в світі за всю їі історію не отримувала диплома на відкриття в області філософії.

На нашу думку, закон рекомбінаційних перетворень може 3 успіхом застосовуватися і під час вивчення різних проблем поліморбідності, зокрема під час вивчення характеру взаємовідносин хвороби за їх одночасного перебігу, що своєю чергою дозволить впритул підійти до розробки основ диференціальної діагностики багатьох захворювань.

Висновки. Окремі випадки комбінаційних перетворень були основою головних відкриттів таких видатних учених, в тому числі лауреатів Нобелівської премії, як А.М. Бутлеров (ізомерія), Г. Мендель (генетичні рекомбінаціі), Ф. Крик, Г.А. Гамов, Л. Барнет, С. Бреннер, Р. Ваттс-Тобін, М. Нірнберг, Дж. Маттеї, О. Очоа (генетичний код), С. Тонегава (молекулярно-генетична теорія утворення антитіл). Однак ніхто 3 них не побачив у частковостях, що їх цікавили, прояви загальної закономірності. Саме Д.С. Саркісов зрозумів, що всі ці факти часткові прояви загального, тобто філософського, закону, який поширюється на живу і неживу природу, суспільство і мис- 
лення, закону, що виражає форму руху матерії, котра до нього ще не була описана. Тому цілком справедливо присудження Д.С. Саркісову пріоритету у цьому відкритті.

Перспективи подальшого розвитку у цьому напрямі. Подальші дослідження будуть спрямовані на аналіз розробленого С.Д. Саркісовим принципу антагоністичної регуляції функцій як філософського вчення.

\section{Jimepamypa:}

1. Лазебник Л.Б., Вёрткин А.Л., Конев Ю.В., Ли Е.Д., Скотников А.С. Старение: профессиональный врачебный подход. Москва : Эксмо, 2013.320 с.

2. Пальцын А.А., Колокольчикова Е.Г. Донат Семенович Саркисов творческий портрет. Вестник Российской Академии медииинских наук. 2002. № 4. С. 47-52.

3. Пальцын А.А. К 85-летию со дня рождения академика РАМН Д.С. Саркисова. Патогенез. 2011. Т. 9, № 1. С. 71-80.

4. Саркисов Д.С. Регенерация и ее клиническое значение. Москва, 1970. $284 \mathrm{c}$

5. Саркисов Д.С., Втюрин Б.В. Электронная микроскопия деструктивных и регенераторных внутриклеточных процессов. Москва, 1967. $260 \mathrm{c}$.

6. Саркисов Д.С., Втюрин Б.В. Электронномикроскопический анализ повышения выносливости сердца. Москва, 1969. $171 \mathrm{c}$.

7. Саркисов Д.С., Пальцын А.А., Втюрин Б.В. Электронно-микроскопическая радиоавтография клетки. Москва, 1980. 264 с.

Potsulko O., Davidov P. "The law of recombination transformations" by D.S. Sarkisov is the fourth law of philosophy

Summary. This article analyzes, on the one hand, the main milestones of the biography of a remarkable person, academician Donat Semenovich Sarkisov, which influenced his becoming a scientist, who left behind a huge amount of both theoretical and practical developments in clinical, general, pathological medicine, as well as philosophy on the other hand, the main stages of the origin and formation of the theory of regeneration, which, in turn, became the basis for the discovery of the 4th law of philosophy - the "Law of recombination transformations". The deep and fundamental "meaning" of recombination transformations in living systems is that without them, in a huge number of cases, such important "quantitative" adaptive processes of the body as regeneration and hyperplasia cannot work: under these conditions they lose one of their main properties - specificity with respect to this pathogenic factor.

Why today, D.S. Sarkisov the only author of a discovery in philosophy in the world - a science that has many great discoveries in its arsenal? The fact is that the discoveries of laws, categories, and concepts of philosophy in their modern formulation are the collective work of many great minds of mankind. Almost all the basic principles of dialectics were expressed by ancient authors. These statements, although not sufficiently clear, poorly proven, with elements of ingenious guesses and naive fantasies, nevertheless, were already philosophical, i.e. having not private, but universal, universal significance that applies to all phenomena of the world. Later philosophers, including modern ones, clarified, developed, coordinated these provisions with the avalanche-like growing material of private sciences. Donat Semenovich has a different situation. Combinational transformations were also known and used by man for a long time. But all of them remained special cases, until the moment when D.S. Sarkisov realized that all these facts are particular manifestations of the universal, that is, philosophical, law that applies to animate and inanimate nature, society and thinking, a law that expresses the form of matter motion that has not been described before. Therefore, the award of D.S. Sarkisov priority in the opening.

Key words: general pathology, intracellular regeneration, law of recombination transformations, clinical medicine, tissue, experiment. 